\title{
Original Documents Testamentary Documents Relating to Property at Totnes Devon
}

\section{W. S. W.}

To cite this article: W. S. W. (1851) Original Documents Testamentary Documents Relating to Property at Totnes Devon, Archaeological Journal, 8:1, 307-312, DOI: 10.1080/00665983.1851.10850835

To link to this article: http://dx.doi.org/10.1080/00665983.1851.10850835

冓 Published online: 10 Jul 2014.

Submit your article to this journal $[\pi$

Q View related articles $\longleftarrow$ 


\section{QBríainal 炀ocuments.}

\section{TESTAMENTARY DOCUMENTS RELATING TO PROPERTY AT TOTNES DEVON.}

AMONGST the miscellaneous evidences connected with the early history and descent of property in the ancient town of Totnes, preserved with family deeds in the possession of John Ayshford Wise, Esq., of Clayton IIall, S Staffordshire, the following Wills have been selected as well deserving of a place in the Jounnal.

Will of Join Hempstone, of Totnes, 1393.

"In Dei nomine, amen. Die veneris in festo Decollacionis sancti Jolannis Baptiste, Anno domini Millesimo ccc $^{\text {mo }}$ Nonogesimo tercio, Ego, Johannes Hempstone de Totteneys, sanno (sic) memor' condo testamentum meum in hunc modum. In prinis, lego animam meam Deo, et corpus meum sacre sepulture. Item, lego priori de Totteneys, pru decimis oblitis, $\mathrm{xl}^{\mathrm{d}}$. Item, lego fabrice beate Marie Totton' $\mathrm{xl}{ }^{\mathrm{d}}$, solvendum $\mathrm{xl}$. vicibus pro summa venie. Item, lego ponti Totton' xij d. Item, lego fratribus leprosis beate Magdalene Totton' $\mathrm{xij}^{\mathrm{d}}$. $^{\mathrm{1}}$ Item, lego vicario Totton' $\mathrm{xij}^{\mathrm{d}}$ ad orandum pro anima mea. Item, lego Thome Cressalle et Jolianni Schrobysbiry monachis inter se xij d. Item, lego fratri de Warlonde vja. Item, lego Henrico Bastarde Capellano vi ${ }^{\mathfrak{a}}$. Item, lego Ricardo Rondelle Capellano $\mathrm{vj}^{\mathrm{d}}$. Item, lego Isolde uxori mee totum illud tenementum meum cum pertinenciis in magna Totton' infra portas, quod est scituatum inter tenementum Ricardi Ballond in parte orient', et tenementum Willelmi Mederose in parte occident', habendum et tenendum predicte Isolde uxori mee ad terminum vite sue, red̄endo inde annuatim capitalibus dominis feodi redditus et servicia inde debita, et de jure consueta. Et post decessum predicte Isolde uxoris mee, lego et concedo totum predictum tenementum cun omnibus suis pertinenciis Johanni filio meo, habendum et tenendum totum predictum tenementum cum omnibus suis pertinenciis, prefato Johanni filio meo et heredibus de corpore suo legitime procreatis, reddendo inde annuatim capitalibus dominis feodi redditus et servicia inde debita et de jure consueta. Et, si contingat, quod absit, prefatum Johannem filium meum sine heredibus de corpore suo legitime procreatis obire, extunc volo et concedo quod totum predictum tenementum cum omnibus suis pertinenciis vendatur per executores meos, si supervixerint prefatum Johannem filium meum ct heredes suos de corpore suo legitime procreatos, vel per executores prefati Johannis filii mei, si executores mei prefatum Johannem filium meum et heredes de corpore suo legitime procreatos non supervixerınt; et quod pecunia inde recepta disponatur pro anima mea, et pro animabus Isolde uxol's mee, Johannis filii mei, et Johannis fratris mei, et omnium antecessorum meorum et omnium fidelium defunctorum. Residuum vero omnium bonorum meorum non legatorum lego Isolde uxori mee et Johanni filio meo, et ipsos ordino, facio et constituo executores meos, ut ipsi, deum pre oculis suis habentes, disponant pro salute anime mee, prout ipsis melius viderit expedire."

(Seal of red wax, of pointed oral form, a moiety remaining, affixed on a

VOL. VIII.

See Dr. Oliver's Monast. Fxon, p. 241. 
slip at the lower margin of the document, cut half across the parchment. The device is a hand holding a covered pyx, resembling a standing cup. At the side of the pyx, above, are two keys. Legend defaced, commencing - Sigillum ...." A second narrower slip, cut below the other, served to tie up the will.) Totton'.'

Original endorsement :- “ Hoc est testamentum Johannis Hempstone de

In a much later hand:- "The wyll of John Hempston, by which he devysed one Tenement in Totnes after the decease of his wyfe to John his sonne in taile, and after that to be solde. Dat. Anno domini, M.iijc.lxxxxiijo."

Will of Ambrose Franike, of Totnes, 1483.

"In Dei nomine, Amen. Anno domini M.cecc ${ }^{0} .1 \times x \times i i j 0, x^{0} v^{0}$ die mensis Februarii. Ego, Ambrosius Franke, de parochia Totton', videns miclii mortis periculum subire, tamen compos mentis, condo testamentum meum in hunc modum. In primis, lego animam meam deo omnipotenti, bente Marie et omnibus sanctis ejus, corpus que meum sacre sepulture in mea ecclesiastica sepultura beate Marie Totton'. Item, lego Johanne filie mee, uxori Ricardi Peletone, sex cocliaria de argento, et unam crateram flat de argento, et unam parvam Murram ligatam cum argento. Item, dimid' pake panni lanei. Item, lego ad Missam de Jh'u $\mathrm{xl}^{\mathrm{d}}$. Item, lego rectori

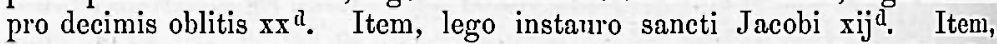
lego instauro beati Marie xija. Item, lego instauro sancte Marie Magdalene xij d. Item, lego instauro sancti Petri vjd. Item, lego Ambrosio servo meo et filio spirituali ultra convencionem suam servicio suo completo $\mathrm{vj}^{\mathrm{g}} \mathrm{viij}^{\mathrm{d}}$, et unam togam meam. Item, lego ad sustentacionem Capelle sancti Edmundi regis et martiris $x l^{d} .^{2}$ Item, lego Oringe uxori mee meum tenementum in quo modo inhabito, durante termino michi consesso (sic); et, si ipsa infra terminum mihi concessum obierit, tune volo quod dictum tenementum remaneat Johanne filie mee et heredibus de corpore suo ligittime procreatis, durante termino mihi concesso; et, si dicta Johanna filia mea infra terminum mili concessum obierit, sine heredibus de corpore suo ligittime procreatis, tunc volo quod dictum tenementum meum, in quo modo inhabito, durante termino mihi concesso remaneat ad sustentacionem Misse de Jh'u. Item, do et lego Oringe uxori mee unum tenementum in vico vocato lychwyl-strete, juxta tenementum Jacobi Lucas, dum ipsa viverit; et, post decessum ejus, volo quod dictum tenementum remaneat Johanne filie mee et heredibus de corpore suo ligittime procreatis; et si contingat predictam Joliannam obire sine heredibus de corpore suo ligittime procreatis, tunc volo quod dictum tenementum remaneat capelle sancte Marie Magdalene, imperpetuum, ad orandum, et c'. Item, lego Oringe uxori mee unum tenementum meum jacens in harperyswylstrete, inter tenementum Johannis Holman et tenementum quod Willelmus Wyke ibidem tenet, dum ipsa viverit; et post ejus decessum volo quod remaneat Johanne filie mee et heredibus de corpore suo ligittime procreatis; et si eontingat dictam Johannam sine heredibus obire, tune volo quod illud tenementum remaneat ad sustentacionem Misse de Jh'u, imperpetuum. Item, lego Ricardo Stephyne iijs ${ }^{\text {iijj }}$ et unam togam. Item, volo et constituo quod post decessum meum unus idoneus sacerdos celebrabit in ecclesia sancte Marie Totton', coram nova cruce, per unum annum, ad orandum pro anima mea, parentum et benefactorum meorum. Residuum

2 This was the Clantry, "ad finem pontis de Totton". Dr. Olirel's Monast. Exon. p. 240. 
vero omnium bonorum meorum non legatorum lego et do executrici mee, ut ipsa faciat et disponat prout viderit deo bene placere, et saluti anime meo melius expedire, et ad istud testamentum fideliter exequendum Oringeam uxorem meam ordino executricem facio et constituo; supervisoremque ordino dompnum Johannem Kyuge, Abbatem de Bukfast. ${ }^{3}$ Datum apud Totton', Anno, die et loco supradictis."

(Seal of red wax, much broken, affixed in like manner, and impressed by the same matrix, as the former.)

Original endorsement:- "Testamentum Ambrosii Frauncke nuper de Totton' M." (Magna?)

In a later hand:- "The testament of Ambrose Francke, by which he deviseth vnto Oringe his wyfe for terme of her lyfe, and after her decease to Joane his dawghter in taile, and for default of such to uses forbydden, two Tenements, of which thone lyeth in Lychwel strete, and thother in IIarpiswill street, in Totnes."

It is remarkable that these two wills, which differ in date no less than ninety years, and do not purport to have been sealed by any one, should have attached to them one and the same seal,-which, though very much broken, is evidently of an ecclesiastical character, but does not appear to be the seal of any ecclesiastical court, or of an officer of any such court. Yet, except so far as any surmise to the contrary may arise from the identity of the seal, there is nothing to indicate that either of them is not the origiual will of the testator. The contemporaneous indorsements, "Testamentum," and "Hoc est testamentum," certainly import rather that they are originals than copies. In addition to which, seeing that they so closely resemble each other, that if either of them be original, in all probability they both are, aud that in the later of them a blank seems to have been left for the name of the supervisor, which was afterwards filled up apparently in a different hand and with different ink (a circumstance hardly reconcileable with the supposition of its being a copy), I confidently conclude they are both originals. In neither case is there any reason to suppose the seal was intended for the testator's ; and had it been that of any ecclesiastical court in which the wills were proved, or of an officer of any such court, it is almost certain the fact of their having been proved would have been stated on them.

In Madox's Form. Angl., pp. 423 and 424, two instances occur of original wills of very early date, having respectively three and four seals appended to them, and there is no reason to think that any one of them was the seal of the testator, or of any ecclesiastical court or officer. Each of the documents under consideration had a second slip of parchment, and one of them retains it; yet it has not the appearance of having been the label of a second seal.

These anomalies are sufficiently rare to merit an attempt to explain them; and if, for this purpose, we glance at the manner in which wills were in those days made, authenticated, and disposed of, it may serve at the same time to extend our acquaintance with the peculiarities of ancient writings of a testamentary lind.

During the period within which these documents respectively bear date,

3 This document supplies the name of an Abbott of Buckfastleigh not before ascertained. In Dr. Oliver's list (Monast. Exon. p. 372) Joln Mutther occurs in 1451 followed by Jolıu Rode in $1 \pm 98$. 
and for many years previously, all property that comes under the denomination of personalty might have been disposed of by a will which was neither signed nor sealed by any one, nor indeed even reduced to writing in the lifetime of the testator. The more formal wills were in writing, and sealed with the testator's seal; but it was no uncommon practice for some one to write down the testator's wishes from his dictation or instructions ; and the writing was then read over to, and approved by, him before witnesses ; and thereupon it became his will. Witnesses were not necessary, if the writing could be otherwise proved, to the satisfaction of the proper ecclesiastical court, to have been the testator's will; and when there were witnesses, their names were often not mentioned either in the document or upon it.

Neither such wills, nor any others however made, were in general effectual for the disposal of land or other property of that lind; but in some ancient boroughs, where Anglo-Saxon customs lingered (and it is not improbable that Totnes may have been one), houses and land might have been so disposed of ; and by means of the intervention of trustees, commonly designated "feoffees to uses," the beneficial interest in land and in whatever is termed real estate was capable of being devised by any will that sufficed for the disposition of personalty.

$\Lambda$ fter the death of the testator the will was proved in some ecclesiastical court ; and a copy of it was made out with a certificate thereon of the fact of probate ; and this was authenticated by the seal of the court or its officer, and delivered to the executors as evidence of their authority. The original will was not then retained by the court as it is at the present day. Occasionally, perhaps, the certificate of probate may have been written on it, and authenticated as before mentioned; in which case it would have been delivered to the executors in the place of a copy. Where this was not done, and the will comprised real as well as personal estate, in all probability it was delivered to some of those to whom the real estate was given, and accompanied the title-deeds : for original wills of early date are not unfrequently found among ancient muniments of title; and in all cases, after the duties of the executorship were fulfilled, there was no other use for them.

The ecelesiastical courts began to preserve and register copies of wills long before they took into their custody the originals. According to returns made about twenty years ago, the practice of preserving copies might be traced back, in some few courts, to the time of Edward II. ; but no original wills were found in any of them earlier than 1500, except, perhaps, a few in the Prerogative Court of Canterbury.

It was considered the duty of the parochial clergy to see that people made proper wills ; nor was this confined to those made in sickness. ${ }^{4}$ Onc of the constitutions of Edmund, Archbishop of Canterbury, in 1236, forbade laymen to make their wills without the presence of the parish priest. The general canon law is even said to have required that the minister of the parish should be present as one of the witnesses. His presence, however, was not, in this country, essential to the validity of a will, nor do these directions appear to have been very generally observed, except, as Lyndwode ${ }^{5}$ states, in certain places where such had become the custom; yet traces of their influence may be found after the reformation, as, for

'Gibson's Codex, 1. 462, edit. 1761.

5 Lyndwosle, p. 127 , cdit. 1525. 
example, in the 84th canon, which directs the clergy from time to time, especially when men make their testaments, to exhort their neighbours to give to the alms-chest in the church ; and in the rubric of the office for the visitation of the sick, which directs the minister to admonish the sick man respecting his will. One reason, perhaps, why the parish priest less frequently appears among the witneases, when any are named, may be that he generally took some benefit under it to say masses for the testator's soul.

From the foregoing observations it is manifest, that we have no cause to question the originality of an ancient will because it does not come out of an ecclesiastical court, or to be surprised that a will has not the testator's seal to it, or any mention in it of its having been sealed, or of there having been any witnesses. In general, when a will is found with several seals, it is a probate copy, and there appear on it certificates of the will having been proved in several courts, the testator having left property in different jurisdictions. Some examples of such documents are to be found in Madox's Form. Angl. But how are we to account for a will having a seal or several seals attached to it, which yet does not purport to have been either sealed or proved? In explanation of this, after having sought in vain for something decisive on the subject, I would offer the following suggestion. Though witnesses to a will were not necessary, it was almost the invariable practice to have not less than two or three, and generally more. At a time when few could write, much less recognise the handwriting of others, if a will were made before witnesses, and not sealed with the testator's seal, especially if he were then in health, it must have been expedient to have some mode of identifying the writing as that which they had heard read over to him ; and what method was more likely to have been resorted to than that some seal, which could be easily recognised, should be attached to it? In the two instances above referred to in Madox's Form. Angl., where there were respectively three and four seals, I conceive them to have been the seals of witnesses themselves ; as no means of identification could be more satisfactory to them than appending their own seals. Those wills are in the past tense and third person, as if memoranda of what took place; but are too long to have been nuncupative wills-i.e., wills not put into writing while the testators were alive, or at least at the time they made them. In other cases of less importance, probably, the witnesses would be content with some well-known seal being affixed; and if the parish priest, in compliance with the constitution of 1236 , was in the habit of being present, no single seal was likely to have been more generally approved than his; and such a practice may have easily led to the use of a particular seal by the priest on such occasions, which would on that account, in some cases, be handed down from one to anther through a succession of incumbents, and become well known. I am, therefore, disposed to think the seal in question was the seal of the parish priest of Totnes for these purposes, and had passed from one to another during the interval that occurred between the dates of the two wills. This appears to me more probable than that it should have been the seal adopted by some notary, evon supposing it had in like manner been transmitted through a succession of such functionaries; because he would have been more likely, from his habits of business, to affix his notarial signature or seal. The silence of the books on such a practice of identifying the writing, and the rarity of the examples of seals so employed, may be accounted for by the fact of the testator's seal 
being always recommended by legal writers, and commonly affixed, and that alone would suffice. Then, as to the second slip, this is much smaller than that on which the seal is, and appears to have been used to bind round the will after it had been folded, so as to conceal the contents ; and it is highly probable it was so employed, and then made fast with a seal to exclude curiosity, just as a modern will is usually sealed up in an envelop? before it is put aside by the testator; for, upon the back of one of these wills (the same on which the second slip remains), where the slip would have been fastened after having been passed round the middle of it, there are portions of a seal left, which had apparently been affixed to make it secure. It may be observed that the seal made use of for that object would not have served the purpose of the witnesses in regard to identifying the writing ; for, beside that it would often be affixed in their absence, it would commonly have been broken before they were called upon to give evidence in support of the will.

It is not improbable that Totnes may have been one of the places alluded to by Lyndwode, in which a custom existed of the parish priest attending when any of his parishioners made their wills. However, before adopting such an opinion, it would be desirable to know something nore of the wills of the inhabitants of that ancient borough in the fourteenth and fifteenth centuries.

If we suppose the seal to have been the official seal of some court, and appended to the original wills to show they had been proved, the absence of the certificates of probate is singular, and no good reason can be assigned for the slips with which they were fastened up, unless they had been originally so used to close the wills, and when each will was proved the second slip was cut, and the seal affixed. But such an explanation of the matter appears to me highly improbable, especially when we remember the instances in which three or four seals are found to the same will.

W. S. W. 